\title{
Computational Fluid Dynamic (CFD) Simulation of Thar Lignite Coal and Sugarcane Bagasse in Entrained Flow Gasifier
}

\author{
Ghulamullah Maitlo*1, Ghulam Abbas Kandhro ${ }^{2}$, Rashid Mustafa Korai ${ }^{1}$, \\ Abdul Karim Shah ${ }^{1}$ and Inamullah Maitlo ${ }^{3}$ \\ ${ }^{1}$ Department of Chemical Engineering, Dawood University of Engineering and Technology, Karachi, Sindh, \\ Pakistan. \\ ${ }^{2}$ Department of Basic Sciences, Mathematics and Humanities, Dawood University of Engineering and Technology, \\ Karachi, Sindh, Pakistan. \\ ${ }^{3}$ Department of Metallurgy and Materials Engineering, Dawood University of Engineering and Technology, \\ Karachi, Sindh, Pakistan. \\ *Corresponding Author Email: metlo2696@yahoo.com \\ Received 03 March 2019, Revised 17 September 2019, Accepted 10 November 2019
}

\begin{abstract}
For the generation of heat and electricity thermochemical conversion of feedstock is the most efficient clean, and environmentally friendly conversion process. In Pakistan, biomass and coal conversion through thermochemical conversion processes has got weighty consideration nowadays. As Pakistan is rich in biomass and coal resources. The producer gas produced from carbon-containing materials contains mainly $\mathrm{CO}, \mathrm{CO}_{2}, \mathrm{H}_{2}$ and $\mathrm{CH}_{4}$. A numerical model of entrained flow gasifier is established to simulate coal, biomass blends through entrained flow gasifier. However, locally available coal deposits contain higher amounts of moisture and ash. Due to high moisture and ash content in coal results in lower reactivity along with the difficulty in handling of ash produced during gasification. In this research work, biomass and coal were cogasified in entrained flow gasifier. The challenges arising because of the varying thermo-physical properties of both feedstocks such as volatile fraction, density and ash are taken into consideration in order to produce engine quality syngas. The feeding rate inside the concentric tube entrained flow gasifier was maintained at $82 \mathrm{~kg} / \mathrm{hr}$. Dry Pakistani coal and sugarcane bagasse were used as a feedstock for gasification. In this study varying mixing schemes were adopted in order to achieve the best performance during the cogasification process. The optimum blending ratio was found at a blending ratio of 35:65 on a weight basis. At the optimum blending ratio, the CGE and CCE was $87 \%$ and $99.8 \%$, respectively.
\end{abstract}

Keywords: Thar coal, Sugarcane bagasse, Simulation, Entrained flow gasifier, Syngas.

\section{Introduction}

Technologies that are efficient in terms of energy generation and environmental friendly are focused nowadays throughout the world due to limited fossil resources. Among various conversion technologies such as thermal, thermochemical, biochemical and chemical processes. Thermochemical conversion of coal and biomass is efficient and environmental friendly [1].
Carbon-containing feedstocks are used for the production of combustible syngas. The main constituents of syngas produced from the reactor are $\mathrm{CO}_{2}, \mathrm{CO}, \mathrm{H}_{2}$, and $\mathrm{CH}_{4}$. The syngas produced from chemical reactions is used in internal combustion engines for power generation, in turbines, generators for electricity production, for chemical productions and for numerous other 
applications [2]. Coal and biomass gasification is conventionally done individually, and explicit gasification of organic matter has achieved maturity. As cogasifcation is considered advantageous over coal or biomass gasification alone [3-5]. Alone gasification of biomass produces higher amounts of tar because the structure of biomass is more complex as compared to coal. The gasification of coal alone generates higher levels of environmental emissions resulting in a serious environmental catastrophe [6]. Besides higher levels of $\mathrm{SO}_{\mathrm{x}}$ and $\mathrm{NO}_{\mathrm{x}}$ emissions, coal gasification produces higher concentration of $\mathrm{CO}_{2}$ emissions as compared to biomass [5]. The cogasification of coal and biomass may be an eyecatching choice as it is economical, environmentfriendly and lowers carbon footprints from the economic and social point of view [7]. Inorganic matter content in biomass is lower as compared to coal and offers additional benefit during blending. However, the coal and biomass feedstocks are potentially dissimilar in numerous behaviors together with the difference in composition and reactivity of both fuels [8]. However, in Pakistani coal gasification, ash fusion problems could be the main obstacle as coal contains a higher percentage of moisture and ash. Co-firing of Pakistani feedstocks (biomass and coal) may meaningfully reduce lagging problems inside the gasifier [9]. In order to minimize operational problems resulting from the co-firing of coal and biomass, operational parameters and reactor configurations are the two most vital parameters through which ash deposition on heat transfer surfaces can be reduced. Among the diverse configurations entrained flow gasifiers have received extensive consideration, whereas for co-gasification fixed bed gasifiers has rarely been taken in considerations [10-11]. The wide application of entrained flow gasifier systems offers better carbon conversion efficiencies and cold gas efficiency as compared to fixed bed gasifiers [12]. The entrained flow biomass gasifiers are best suited for coal and biomass co-firing due to an elevated temperature around $\left(1200^{\circ} \mathrm{C}\right.$ to $\left.1500^{\circ} \mathrm{C}\right)$. In entrained flow gasifiers such configurations of high heating rates subsequently compensate for varying reactivity of coal and biomass feedstocks [13]. However, commercially available entrained flow gasifiers are used mostly for syngas [13]. Co-firing plants are generally examined using simulation and modeling approaches available in literature having diverse objectives and applications [14-15]. Different oxidizing agents and their arrangements are introduced in gasifiers that technically effect on the quality of syngas. Oxidizing agents normally used include steam, air, steam, steam oxygen, oxygenenriched air, however, the most common oxidizing agent used during co-firing is air [16]. Nevertheless, accurate simulation and modeling of co-gasification along with a prediction of optimum operating conditions are fundamental in view of chemical equilibrium achievability [17]. Hence developing a model that provide accurate results is a challenging task. In coal and biomass cogasification main reactions occurring are discussed below.

Different types of gasifiers are used for syngas production including fixed bed, fluidized bed and entrained flow gasifiers [18]. Furthermore, entrained flow gasifier was selected for the conversion of sugarcane bagasse and thar coal. As the carbon conversion efficiency and syngas quality is higher when feedstock is gasified using entrained flow gasifier [19]. Moreover it would be anticipated that the findings of the present research will be helpful to design and operate the entrained flow gasifier economically and efficiently. It is also expected that the cogasification will help in increasing syngas yield and quality. Globally the different reactions during gasification particularly water-gas shift reaction play a key role during the thermal conversion process, which would be expected in present research as well. The research will also be helpful to manage the low ranked fuels like sugarcane bagasse and thar lignite for the gasification.

\section{Dehydration}

Dehydration is the removal of water from a substance as no agricultural residue is completely moisture-free. In its formation, some quantity of water always exists in agricultural waste. During the moisture removal step, vaporization of moisture always takes place for getting dry feedstock, the vapor produced during the evaporation process may contribute in later processing steps. 


\section{Pyrolysis}

In gasifiers operating temperature is maintained more than $1000^{\circ} \mathrm{C}$ during the gasification process. The feedstock introduced in the gasifier, first experiences pyrolysis step in which complex chemical reactions initiate gradually from $150^{\circ} \mathrm{C}$ to $700^{\circ} \mathrm{C}$. The pyrolysis process during the gasification takes place in the absence of oxygen. The products obtained during the pyrolysis step are $\mathrm{H}_{2}, \mathrm{H}_{2} \mathrm{O}, \mathrm{CO}_{2}, \mathrm{CH}_{4}, \mathrm{CO}$, char, and ash as presented in reaction (1). The $(\alpha)$ in reaction (1) shows the number of moles of the species after post-pyrolysis of feedstock.

$\mathrm{Coal} \rightarrow \alpha_{1} \mathrm{CH}_{4}+\alpha_{2} \mathrm{H}_{2}+\alpha_{2} \mathrm{CO}+\alpha_{4} \mathrm{CO}_{2}+\alpha_{5} \mathrm{H}_{2} \mathrm{O}+$
$\alpha_{6} \mathrm{Char}+\alpha_{7}$ Ash

\section{Combustion of Volatile Fraction}

As in pyrolysis reaction (1), a volatile fraction of feedstock included $\mathrm{H}_{2}, \mathrm{CO}_{2}, \mathrm{CH}_{4}, \mathrm{CO}$, $\mathrm{H}_{2} \mathrm{O}$, and nonvolatile fraction includes char. The volatile species $\mathrm{H}_{2}, \mathrm{CH}_{4}$ and $\mathrm{CO}$ gases in the pyrolysis reaction are combustible gases. Such combustible gases produced during pyrolysis step react with the gasifying agent. The main reactions are shown as [20].

$$
\begin{aligned}
& \mathrm{CO}+0.5 \mathrm{O}_{2} \rightarrow \mathrm{CO}_{2}\left(\Delta \mathrm{H}=283 \frac{\mathrm{MJ}}{\mathrm{kmol}}\right) \\
& \mathrm{H}_{2}+0.5 \mathrm{O}_{2} \rightarrow \mathrm{H}_{\mathrm{O}}\left(\Delta \mathrm{H}=242 \frac{\mathrm{MJ}}{\mathrm{kmol}}\right) \\
& \mathrm{C}+0.5 \mathrm{O}_{2} \rightarrow \mathrm{CO}\left(\Delta \mathrm{H}=111 \frac{\mathrm{MJ}}{\mathrm{kmol}}\right)
\end{aligned}
$$

\section{Feedstock Gasification}

The heat energy required for endothermic reactions to happen is derived from the exothermic volatile combustion reactions as given in Eq. (2), (3) and (4). The char remaining within the gasifier reacts with steam and $\mathrm{CO}_{2}$ to generate producer gas. Syngas generated consist of $\mathrm{H}_{2}$ and $\mathrm{CO}$ as main products in syngas composition. The reactions involved are given below [21].

$$
\mathrm{C}+\mathrm{H}_{2} \mathrm{O} \leftrightarrow \mathrm{CO}+\mathrm{H}_{2}\left(\Delta \mathrm{H}=131 \frac{\mathrm{MJ}}{\mathrm{kmol}}\right)
$$

$$
\begin{aligned}
& \mathrm{C}+\mathrm{CO}_{2} \leftrightarrow 2 \mathrm{CO}+\left(\Delta \mathrm{H}=172 \frac{\mathrm{MJ}}{\mathrm{kmol}}\right) \\
& \mathrm{C}+2 \mathrm{H}_{2} \leftrightarrow+\mathrm{CH}_{4}\left(\Delta \mathrm{H}=75 \frac{\mathrm{MJ}}{\mathrm{kmol}}\right)
\end{aligned}
$$

\section{Steam Reforming and Water-gas-shift Reactions}

Reactions from 5 to 7 are combustion reactions and occur in the presence of the gasifying agent. Three heterogeneous reactions (reaction 5 to 7) under high carbon conversion conditions can possibly reduce as a substitute to two homogenous reactions in the gas phase. Whereas reaction 8 and 9 are vital reactions for obtaining equilibrium composition of producer gas.

$$
\begin{aligned}
& \mathrm{CO}+\mathrm{H}_{2} \mathrm{O} \leftrightarrow \mathrm{CO}_{2}+\mathrm{H}_{2}\left(\Delta \mathrm{H}=41 \frac{\mathrm{MJ}}{\mathrm{kmol}}\right) \\
& \mathrm{Co}+3 \mathrm{H}_{2} \leftrightarrow \mathrm{CH}_{4}+\mathrm{H}_{2} \mathrm{O}\left(\Delta \mathrm{H}=206 \frac{\mathrm{MJ}}{\mathrm{kmol}}\right)
\end{aligned}
$$

\section{Materials and Methods \\ Geometry Development (CFD)}

The computational domain of geometry of concentric tube entrained flow gasifier was developed through the application of CFD software. Appropriate governing equations were selected for reaction study after the development of the computational domain. The CFD software predicted the behavior of different gasification operational parameters and the syngas composition after the conversion of feedstock into product gas.

\section{CFD Domain}

The Thar lignite coal and bagasse in varying proportions were gasified through the application of concentric tube entrained flow gasifier under atmospheric conditions. Step by step procedure followed in this study is given in (Fig. 1).

Fig. 2a represents the geometry of a developed domain. The meshing of geometry was created through Ansys meshing registered version and is represented in (Fig. 2b). The type of mesh is tetrahedral and the size of the mesh is 77188 cells. Cylindrical type geometry of entrained flow 
gasifier was developed in order to provide ease in mixing of feedstock and gasifying agent during gasification operations [22].

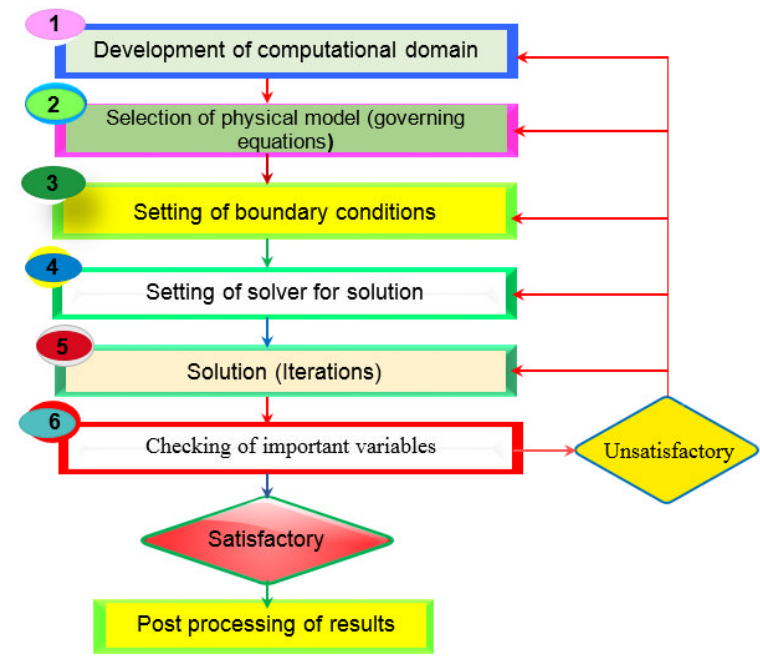

Figure 1. Presents the step by step procedure of CFD simulation

Oxygen as a gasifying agent was used during gasification. Thar lignite coal and bagasse were introduced from the top of the gasifier. Oxygen was introduced via the outer ring that was concentric with the inner tube of gasifier whereas thar lignite coal and bagasse were injected from the central tube.
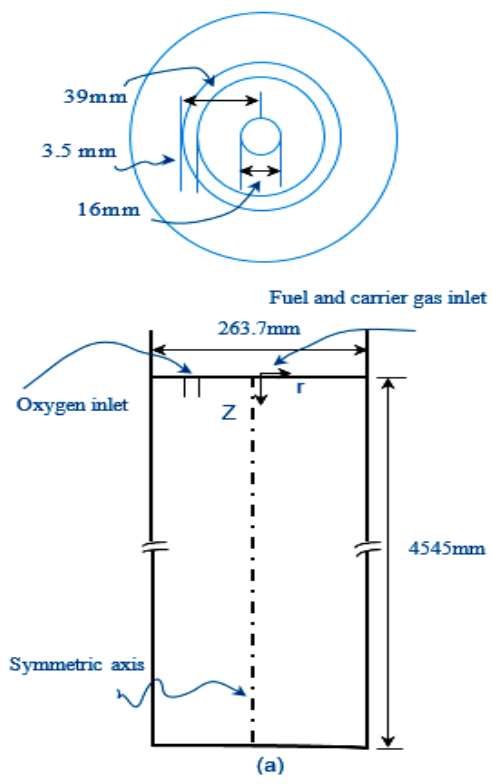

Figure 2a. Geometry of entrained flow gasifier

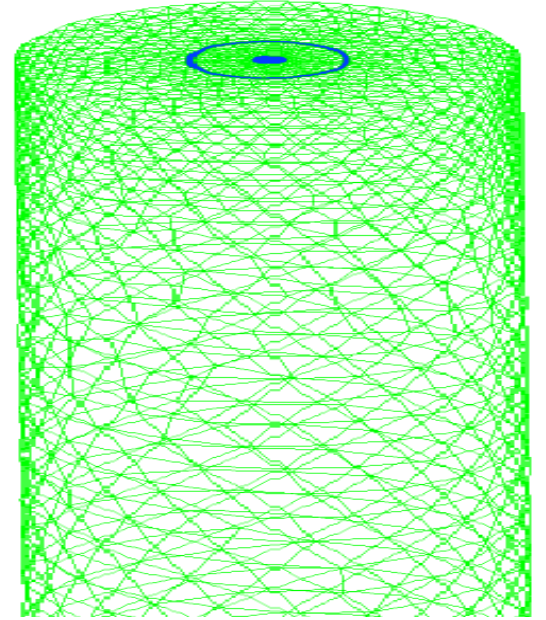

Figure 2b. Mesh of Gasifier

Sugarcane bagasse and Thar coal were used as a raw material for co-gasification. Table 1 shows the proximate and ultimate analysis results of thar coal and sugarcane bagasse. Proximate analysis was performed as per the ASTM standard method D7582, the ultimate analysis was done with Thermo Fisher Flash 2000 Elemental Analyzer, whereas for HHV estimation bomb calorimeter was used.

Table 1.Characterization of thar lignite and sugarcane bagasse.

\begin{tabular}{lll}
\hline Parameters & $\begin{array}{l}\text { Thar } \\
\text { lignite }\end{array}$ & Sugarcane bagasse \\
\hline Proximate study (ad, wt. \%) & & \\
M & 7.18 & 5.96 \\
VM & 32.92 & 76.77 \\
FC & 42.19 & 12.17 \\
A & 17.8 & 5 \\
Ultimate study (daf, wt. \%) & \\
C & 72.5 & 48.8 \\
H & 7.2 & 7.4 \\
N & 1.05 & 0.26 \\
S & 1.4 & 0.16 \\
O* & 17.85 & 43.4 \\
HHV $\left(\mathrm{MJ} \mathrm{kg}^{-1}\right)$ & 21.06 & 16.99 \\
\hline
\end{tabular}

*By difference.

\section{Analysis of Simulated Results}

Analysis of simulated data was performed regarding CGE, CCE, and HHV through following formulae. 


\section{Higher Heating Value}

For the calculation of syngas HHV following equation was applied.

$$
\mathrm{HHV}\left(\frac{\mathrm{MJ}}{\mathrm{kg}}\right)=\frac{\mathrm{CO}(\%) \times 283+\mathrm{H}_{2}(\%) \times 242+\mathrm{CH}_{4}(\%) \times 795}{\mathrm{MW}_{\text {mix }} \times 100}(
$$

Where (\%) represents the volumetric of the syngas and " $\mathrm{MW}_{\text {mix }}$ " shows the molecular weight of the mixture.

\section{Cold Gas Efficiency}

CGE of syngas $(n c)$ was calculated using following equation

$$
\mathrm{n}_{\mathrm{c}} \frac{\text { product gas flow rate }\left(\frac{\mathrm{Nm}^{3}}{\mathrm{hr}}\right) \times \mathrm{HHV} \text { of gas }\left(\frac{\mathrm{MJ}}{\mathrm{m}^{3}}\right)}{\text { solid fuel flow rate }\left(\frac{\mathrm{kg}}{\mathrm{h}}\right) \times \mathrm{HHV} \text { of solid fuel }\left(\frac{\mathrm{MJ}}{\mathrm{mg}}\right)}
$$

Conversion of carbon to gas $\mathrm{X}_{1}$ was analyzed with the below-mentioned equation (12).

$$
\mathrm{X}_{1}(\%)=\frac{\mathrm{Y} \times\left(\mathrm{CO}(\%)+\mathrm{CO}_{2}(\%)+\mathrm{CH}_{4}(\%)\right) \times 12}{22.4 \times \mathrm{C}(\%)}
$$

Here " $\mathrm{C}(\%)$ " is the carbon mass percent obtained through ultimate analysis of coal or biomass " $\mathrm{Y}(\%)$ " represents dry gas production.

\section{Carbon Conversion}

For the calculation of carbon conversion to char following formula was applied.

$$
\mathrm{X}_{2}(\%)=\frac{\text { Carbon in residual solid }}{\text { Carrbon in fuel }}
$$

\section{Results and Discussion Temperature Effect on Gasification}

As mentioned in the above reactions that temperature has a substantial effect on the gasification and is considered a significant element during the operation of an entrained flow gasifier [23-24]. During cogasification study collected results revealed about best synergetic effects at $35 \%$ sugarcane bagasse mass ratio and at $\mathrm{O} / \mathrm{F}$ ratio $0.41 \mathrm{~g} / \mathrm{g}$. In Fig. 3a, $3 \mathrm{~b}$ and $3 \mathrm{c}$ influence of temperature difference on the performance of gasifier is shown. The results obtained revealed that the major constituents of syngas were $\mathrm{CO}$ and $\mathrm{H}_{2}$, while the mole fractions of $\mathrm{CO}$ in synthesis gas composition was higher than the mole fractions of $\mathrm{H}_{2}$.
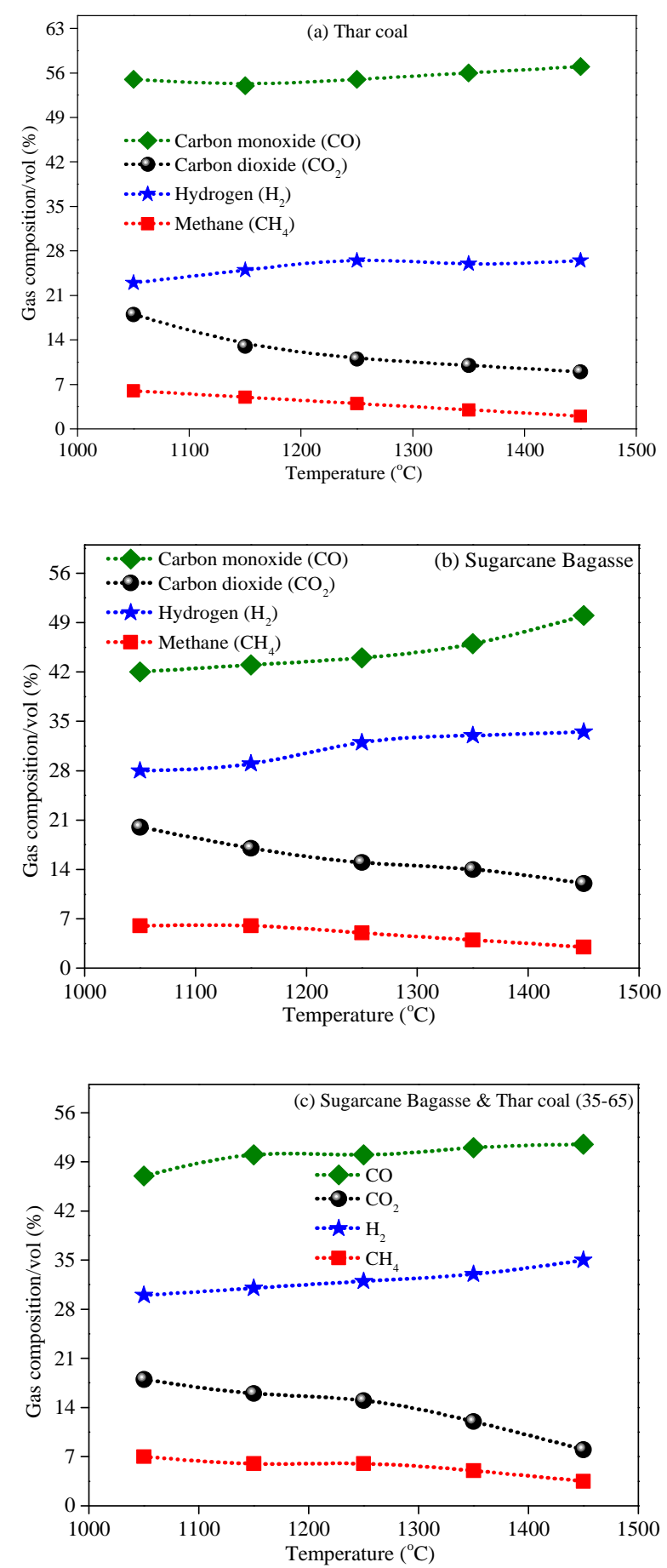

Figure 3.Influence of temperature on syngas components (a) Thar coal (b) sugarcane bagasse (c) Thar coal and sugarcane bagasse 
With the rise in temperatures of the gasifier, the concentration of $\mathrm{CO}$ and $\mathrm{H}_{2}$ in syngas composition increased. Whereas the opposite trend was observed in the case of $\mathrm{CO}_{2}$ and $\mathrm{CH}_{4}$. However, during the operation of the gasifier, the pyrolysis, volatile decomposition was noticed and after that char gasification occurred during the cogasification processes. With the rise in gasification temperature, the reduction reactions (14), (15), (16) were favored and resulted in increased mole fractions of $\mathrm{CO}$ and $\mathrm{H}_{2}$. Whereas when the reactor temperature increased above $1050^{\circ} \mathrm{C}$, reaction (14) became more dominant than reaction (15), because of that more $\mathrm{CO}$ was produced as compared to $\mathrm{H}_{2}$ [23].

$$
\begin{aligned}
& \mathrm{C}+\mathrm{CO}_{2} \leftrightarrow 2 \mathrm{CO} \Delta \mathrm{H},=172.22 \frac{\mathrm{kJ}}{\mathrm{mol}} \\
& \mathrm{CH}_{4}+\mathrm{H}_{2} \mathrm{O}(\mathrm{g}) \rightarrow 3 \mathrm{H}_{2}+\mathrm{CO}, \Delta \mathrm{H}=\frac{206.2 \mathrm{~kJ}}{\mathrm{~mol}}
\end{aligned}
$$

In Fig. 3 the influence of temperature on CGE is illustrated. As with increasing temperature, the production of $\mathrm{CO}$ and $\mathrm{H}_{2}$ enhanced which may be due to the dominant position of reactions (14), (15) and (16) endothermic gasification reactions.

\section{Effect of Sugarcane Bagasse Mass Ratio}

Fig. 4 reveals the influence of sugarcane bagasse blending ratio on the composition of syngas under the temperature $1350^{\circ} \mathrm{C}$ and under varying oxygen to fuel ratios.

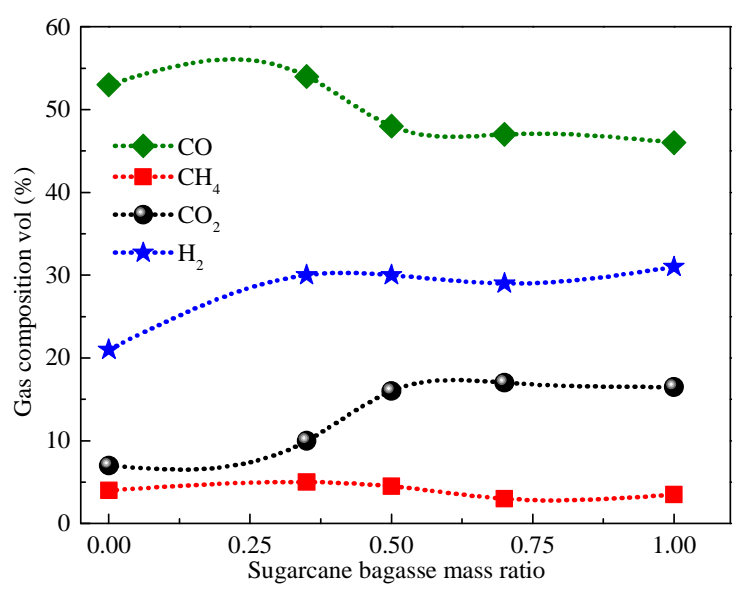

Figure 4.Influence of sugarcane bagasse mass ratio on gas yield
During the gasification process, the production of $\mathrm{H}_{2}$ was primarily affected by the $\mathrm{C} / \mathrm{H}$ ratio in the raw material used for gasification, reaction temperature, and reaction atmosphere. The higher values of $\mathrm{C} / \mathrm{H}$ results in more productions of $\mathrm{H}_{2}$ in syngas composition [25].

The carbon and hydrogen values of biomass and coal are presented in Table 1, therefore the $\mathrm{C} / \mathrm{H}$ ratio was calculated from (Table 1). When the proportion of sugarcane bagasse was increased, it resulted in an enhanced ratio of hydrogen to carbon in the feedstock. However, because of the enhanced hydrogen ratio more, the mole fraction of $\mathrm{H}_{2}$ was produced. While in case of $\mathrm{CO}_{2}$ production opposite trend in mole fractions were observed as compared to $\mathrm{CO}$. The variations in $\mathrm{CO}$ and $\mathrm{CO}_{2}$ production was mainly due to the ratio of oxygen to fuel in the gasification equipment enhanced with the addition of biomass as compared to the coal gasification alone. The lower heating value of syngas was observed maximum of $15.26 \mathrm{MJ} / \mathrm{m}^{3}$ at $35 \%$ sugarcane bagasse mass ratio. The higher heating value of syngas $15.26 \mathrm{MJ} / \mathrm{m}^{3}$ was higher than that of individual gasification of Thar coal and sugarcane bagasse. The synergistic effect was most apparent when the sugarcane bagasse mass ratio was $35 \%$. The CCE improved meaningfully with the rising of sugarcane bagasse mass ratio, the cold gas efficiency was observed maximum of $74 \%$ at sugarcane mass ratio $35 \%$.

\section{Influence of $\mathrm{O} / \mathrm{F}$ Ratio}

In Fig. 5 the performance of gasification under different oxygen-fuel ratio is shown at temperature $1350^{\circ} \mathrm{C}$. The percent of $\mathrm{H}_{2}$ and $\mathrm{CH}_{4}$ in producer gas reduced with increasing oxygen-fuel ratio. Moreover, the opposite trend was observed in the proportion of $\mathrm{CO}$ and $\mathrm{CO}_{2}$ in contrast to $\mathrm{H}_{2}$. While with an increase in $\mathrm{O} / \mathrm{F}$ ratio in the range of 0.28 to 0.50 , as $\mathrm{H}_{2}$ reacted with $\mathrm{O}_{2}$ producing $\mathrm{H}_{2} \mathrm{O}$. The $\mathrm{H}_{2} \mathrm{O}$ reacted with char and enhanced the formation of $\mathrm{CO}$ in syngas yield. Additionally, as the $\mathrm{O} / \mathrm{F}$ ratio was enhanced, the $\mathrm{O}_{2}$ reacted with char, $\mathrm{CO}, \mathrm{H}_{2}$ and $\mathrm{CH}_{4}$ generated more proportions of $\mathrm{CO}_{2}$. 

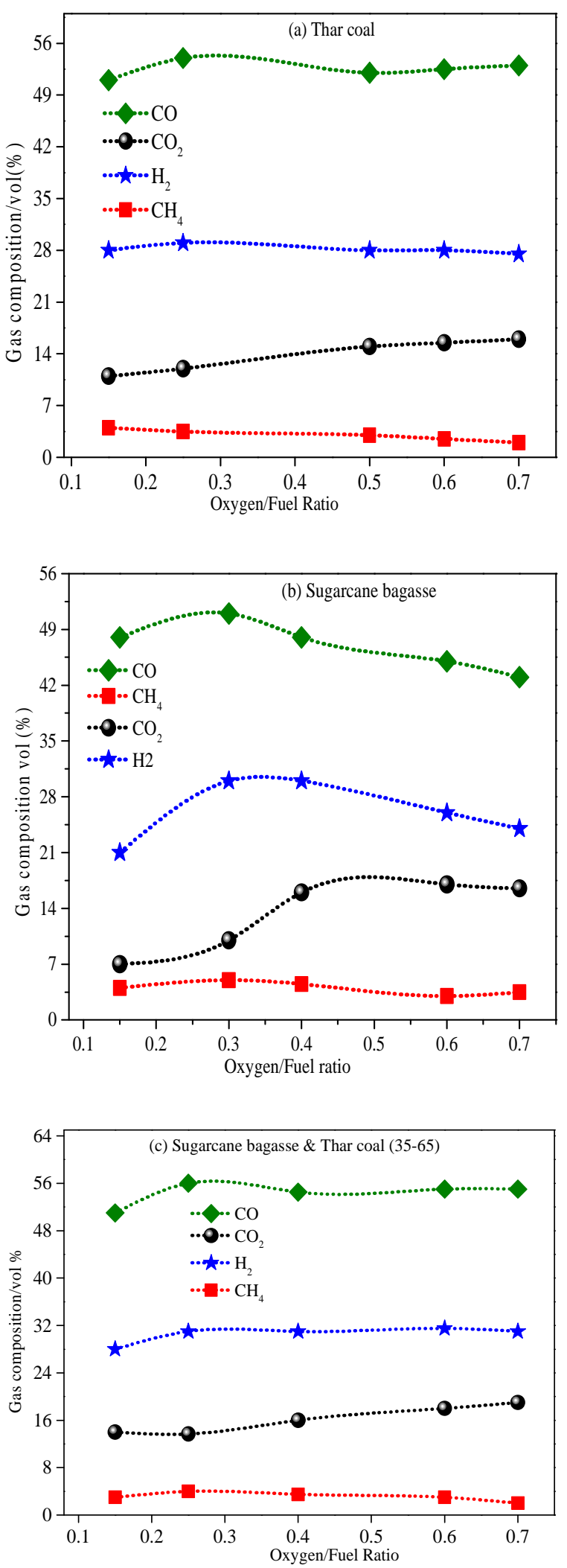

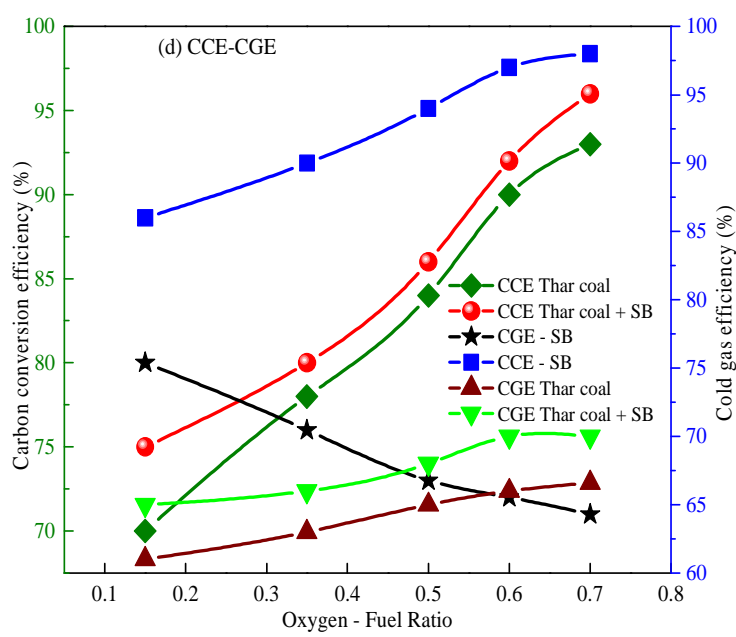

Figure 5.Effect of $\mathrm{O} / \mathrm{F}$ ratio (a) Thar coal, (b) sugarcane bagasse (c) mixing of Thar coal and sugarcane bagasse (d) CCE \& CGE

The LHV of thar coal synthesis gas firstly increased from $14.16 \mathrm{MJ} / \mathrm{m}^{3}$ to $14.98 \mathrm{MJ} / \mathrm{m}^{3}$ and then with growing $\mathrm{O} / \mathrm{F}$ ratio lower heating value of product gas decreased. In Fig. 5d the effect of oxygen-fuel ratio on syngas yield, CCE and CGE during co gasification is represented. Moreover, at the oxygen-fuel ratio 0.63 , the carbon conversion efficiency was more than $98 \%$, whereas as at the same oxygen-carbon ration the cold gas efficiency was low. The optimum oxygen-fuel ratio for better quality syngas gas was 0.38 . The contours of different gas species are presented in Fig. 6a-e.

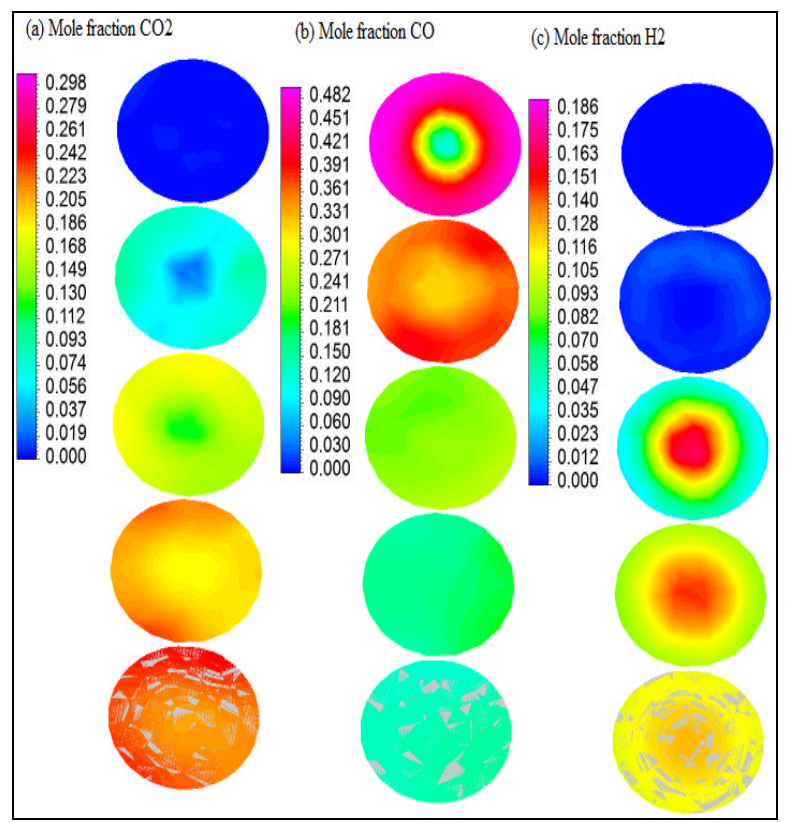




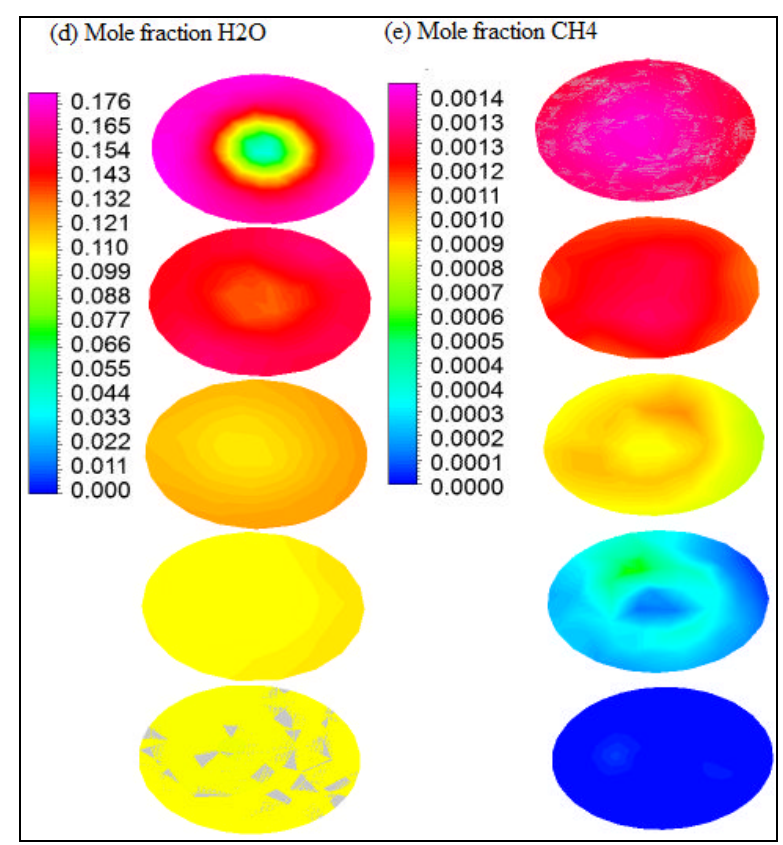

Figure 6.Contours of gas species (a) $\mathrm{CO}_{2}$ (b) $\mathrm{CO}$ (c) $\mathrm{H}_{2}$ (d) $\mathrm{H}_{2} \mathrm{O}$ (e) $\mathrm{CH}_{4}$

Furthermore, important components of syngas were compared with the published international literature. The syngas components compared with the study of other researchers include $\mathrm{CO}, \mathrm{CO}_{2}, \mathrm{CH}_{4}$, and $\mathrm{H}_{2}$. Fig. 7 shows the comparison of results with other studies conducted by various researchers. The results of $\mathrm{CH}_{4}, \mathrm{CO}_{2}$, and $\mathrm{CO}$ are in good agreement with the results investigated by other researchers. Moreover little bit variations in $\mathrm{CO}_{2}$ production is observed that may be due to the gasifying agent used during the cogasification of coal and biomass.

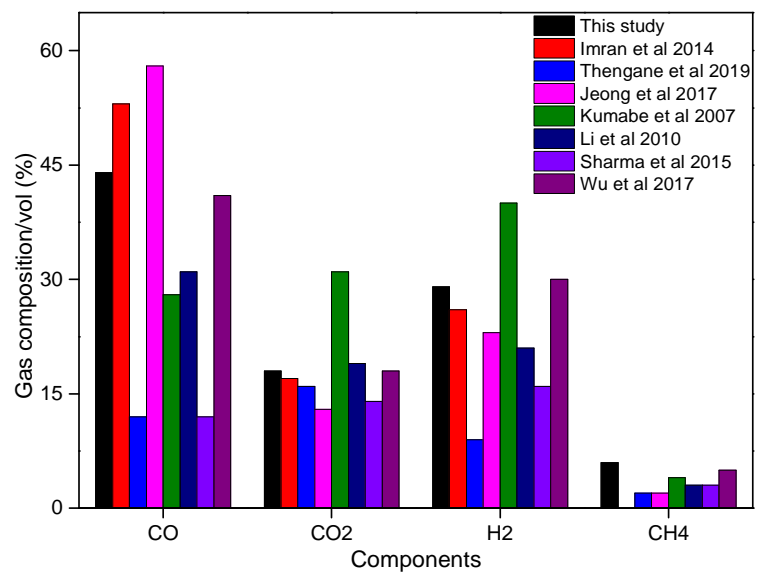

Figure. 7. Comparison of results with international literature

\section{Conclusion}

The performance evaluation of cogasification of Thar coal and sugarcane bagasse was done through the application of concentric tube entrained flow gasifier. The consequence of different functioning factors including the effect of temperature variations, the blending effect of Thar coal and sugarcane bagasse ratio, the effect of oxygen-fuel ratio on gaseous product distribution, CCE, CGE and LHV was examined. The blending of sugarcane bagasse with coal increases the gasification performance of the mixture. The positive synergetic effect was noticed between sugarcane bagasse and thar coal on co-gasification performance. It was deduced from the results of a concentric tube entrained flow gasifier that operational temperature posed significant effect on gasifier performance. The appropriate temperature for co-gasification of Thar coal and sugarcane bagasse for better quality syngas was $1450^{\circ} \mathrm{C}$. With the increase in the proportion of sugarcane bagasse in Thar coal increased the mole fractions of $\mathrm{H}_{2}$ and $\mathrm{CO}_{2}$ in syngas composition. At blending of $35 \%$ mass ratio of sugarcane bagasse with Thar coal revealed the most significant synergetic effects during co-gasification. The appropriate operational conditions for co-gasification of Thar coal and sugarcane bagasse concluded in this study for better quality syngas production were: cogasification temperature of $1450^{\circ} \mathrm{C}$. The optimum oxygen-fuel ratio was 0.38 and the optimum mixing ratio of sugarcane bagasse was found $35 \%$. In the future, this simulation study will help in the fabrication of experimental gasifier at industrial scale. The syngas produced through entrained flow gasifier may be analyzed qualitatively and quantitatively. Concentric tube entrained flow gasifier efficiency may be calculated through the application of other gasifying agents such as steam.

\section{Acknowledgment}

All authors are extremely thankful to DUET, Karachi and MUET Jamshoro for providing facilities and technical support during this study. 


\section{References}

1. R. Azargohar, R. Gerspacher, A. K. Dalai and D.Y. Peng, Fuel Process Technol., 134 (2015) 310. doi: 10.1016/j.fuproc.2015.02.014.

2. S. Heidenreich and P. U. Foscolo, Prog. Energ. Combust., 46 (2015) 2015. doi: org/10.1016/j.pecs.2014.06.002.

3. J. Fermoso, B. Arias, M. G. Plaza, C. Pevida, F. Rubiera and J. J. Pis, Fuel Process Technol., 90 (2009) 926. doi: org/10.1016/j.fuproc.2009.02.006.

4. M. W. Seo, J. H. Goo, S. D. Kim, S. H. Lee and Y. C. Choi, Energ Fuel., 24 (2010) 3108 . doi: 10.1021/ef100204s.

5. Y. G. Pan, E. Velo, X. Roca, J. J. Manyà and L. Puigjaner, Fuel, 79 (2000) 1317. doi: org/10.1016/S0016-2361(99)00258-6.

6. M. Sami, K. Annamalai and M. Wooldridge, Prog. Energ Combust., 27 (2001) 214. doi: org/10.1016/S0360-1285(00)00020-4.

7. J. J. Hernández, G. Aranda-Almansa and C. Serrano, Energ. Fuel, 24 (2010) 2479. doi: 10.1021/ef901585f.

8. N. Howaniec and A. Smoliński, Int. J. Hydrog. Energ., 38 (2013) 16152. doi:org/10.1016/j.ijhydene.2013.10.019.

9. X. Fang and L. Jia, Bioresour. Technol., 104 (2012) 769. doi: org/10.1016/j.biortech.2011.11.055.

10. T. R. McLendon, A. P. Lui, R. L. Pineault, S. K. Beer and S. W. Richardson, Biomass Bioenerg., 26 (2004) 377. doi: org/10.1016/j.biombioe.2003.08.003.

11. J. F. Vélez, F. Chejne, C. F. Valdés, E. J. Emery and C. A. Londoño, Fuel, 88 (2009) 424.

doi: org/10.1016/j.fuel.2008.10.018.

12. M. Asadullah, Renew. Sust. Energ. Rev., 29 (2014) 201. doi: org/10.1016/j.rser.2013.08.074.

13. A. Valero and S. Usón, Energy, 31 (2006) 1643. doi: org/10.1016/j.energy.2006.01.005.

14. I. Adeyemi, I. Janajreh, T. Arink and C. Ghenai, Appl. Energ., 185 (2017) 1007. doi:org/10.1016/j.apenergy.2016.05.119.
15. I. Adeyemi and I. Janajreh, Renew. Energ., 82 (2015) 77.

doi: org/10.1016/j.renene.2014.10.073.

16. P.C. Kuo, W. Wu and W.H. Chen, Fuel, 117 (2014) 1231. doi: org/10.1016/j.fuel.2013.07.125.

17. S. M. Beheshti, H. Ghassemi and R. Shahsavan-Markadeh, Energ. Convers. Manag., 94 (2015) 345. doi: org/10.1016/j.enconman.2015.01.060.

18. D. G. Roberts, S. P. S. Badwal, L. J. Wibberley and S. Bhattacharya, Fuel Chem. Prod., 1 (2017) 217. https://doi.org/10.1016/B978-0-08-1008959.00010-3.

19. X. Ku, J. Wang, H. Jin and J. Lin, Renew. Energy., 139 (2017) 781. https://doi.org/10.1016/j.renene.2019.02.113

20. X. Kong, W. Zhong, W. Du and F. Qian, Chin. J. Chem. Eng., 21 (2013) 79. doi: org/10.1016/S1004-9541(13)60444-9.

21. R. Sharma, R. Kumar, I. Kumar and U. Sharma, Eur. J. Org. Chem., 2 (2015) 155. doi: 10.1002/ejoc.201501246.

22. C. H. Shen, W. H. Chen, H. W. Hsu, J. Y. Sheu and T. H. Hsieh, Int. J. Energ. Res., 36 (2012) 499. doi: 10.1002/er.1821.

23. J. G. Lee, J. H. Kim, H. J. Lee, T. J. Park and S. D. Kim, Fuel, 3 (1996) 1035. doi: org/10.1016/0016-2361(96)00084-1.

24. S. Kajitani, Y. Zhang, S. Umemoto, M. Ashizawa and S. Hara, Energ. Fuel, 24 (2010) 151. doi: 10.1021/ef900526h.

25. L. Q. Wang and Z. S. Chen, Appl. Therm. Eng., 59 (2013) 278. doi:org/10.1016/j.applthermaleng.2013.05.042.

26. I. N. Unar, L. Wang, A. G. Pathan and R. B. Mahar, R. Li, Energ. Convers. Manag., 86 (2014) 670. doi.org/10.1016/j.enconman.2014.06.028.

27. K. Sonal, Thengane, A. G. Sanjay and M. Mahajani, Bioresour. Technol., 4 (2018) 31. doi.org/10.1016/j.biortech.2018.11.007.

28. H. J. Jeong, I. S. Hwang and S. S. Park, J. Hwang Fuel, 196 (2017) 371. doi.org/10.1016/j.fuel.2017.01.103. 
29. K. Kumbabe, T. Hanaoka, S. Fujimoto, T. 31. M. Sharma, S. Attanoor and S. Dasappa, Minowa and K. Sakanishi, Fuel, 86 (2007) 684.

doi:10.1016/j.fuel.2006.08.026. Fuel Process Technol., 138 (2015) 435. doi.org/10.1016/j.fuproc.2015.06.015.

30. K. Lia, R. Zhanga and J. Bia, Int. J. Hydrog. Energ., 35 (2010) 2722. doi:10.1016/j.ijhydene.2009.04.046.

32. Z. Wu, H. Meng, Z. Luo, L. Chen and J. Zhao, Int. J. Hydrog. Energ., 42 (2017) 1888.

doi.org/10.1016/j.ijhydene.2017.05.144. 